\title{
Longitudinal follow-up of physical activity from preschool to school age: the ELOS-Pré study
}

\section{Acompanhamento longitudinal da atividade física da idade pré-escolar à escolar: o estudo ELOS-Pré}

\author{
Simone Storino Honda Barros \\ (D) https://orcid.org/0000-0002-0796-5855 \\ Markus Vinicius Nahas ${ }^{2}$ \\ (D) https://orcid.org/0000-0002-4378-4031 \\ Carla Menêses Hardman ${ }^{1,3}$ \\ (D) https://orcid.org/0000-0002-4355-0112 \\ Jorge Bezerra ${ }^{1,4}$ \\ (D) https://orcid.org/0000-0002-9935-4508 \\ Mauro Virgílio Gomes de Barros ${ }^{1,4}$ \\ (D) https://orcid.org/0000-0003-3165-0965
}

Abstract - The aim of this study was to verify if the practice of physical activity in the preschool age (3-5 years) is predictive of this behavior after entering the school age (5-7 years). A longitudinal, school-based study with 700 children enrolled in public and private schools of the city of Recife, Pernambuco, who were evaluated in 2010 and followed in 2012. The study variables were the time spent in outdoor games and plays (a measure referred to by the parents / guardians of children through questionnaire applied as an interview) and the level of physical activity (objective measure obtained by the Actigraph accelerometer). The latter measure was extracted from a subsample $(\mathrm{n}=98)$ of children. To analyze data, binary logistic regression was used. Children who spent $60+$ minutes per day in this type of activity were $45 \%$ more likely of maintaining this behavior after entering the school age $(\mathrm{OR}=1.45,95 \%$ CI 1.02-2.07, $\mathrm{p}=0.04)$. In addition, children who presented global NAF measure of 300+ counts / minute in 2010 were $173 \%$ more likely of maintaining this level of physical activity after entering the school age $(\mathrm{OR}=2.73,95 \% \mathrm{CI}, 98-7.59, \mathrm{p}=0.06)$. It was verified that the practice of physical activity in the preschool age is a predictor of this behavior after entering the school age. It is suggested the development of campaigns to inform parents and teachers about the importance of early adherence to physical activity recommendations.

Key words: Child; Motor activity; Preschool.

Resumo - Objetivou-se verificar se a prática de atividade física na fase pré-escolar (3-5 anos) é preditora desta conduta após o ingresso na fase escolar (5-7 anos). Estudo longitudinal, de base escolar, realizado com 700 crianças avaliadas em 2010 e acompanhadas em 2012, matriculadas em escolas (públicas e privadas) da cidade do Recife, Pernambuco. As variáveis do estudo foram o tempo despendido em jogos e brincadeiras ao ar livre (medida referida pelos pais/responsáveis das crianças por meio de um questionário aplicado em forma de entrevista) e o nível de atividade física (medida objetiva obtida por acelerômetro Actigraph). Esta última medida foi extraída de uma subamostra $(n=98)$ de crianças. Para análise dos dados recorreu-se a regressão logística binária. As crianças que despendiam, em 2010, 60+ minutos/dia neste tipo de atividade apresentaram chance 45\% superior de manter este comportamento após o ingresso na fase escolar (OR=1,45; IC95\% 1,02-2,07; $p=0,04)$. Além disso, as crianças que, em 2010, apresentaram medida global do NAF de 300+ counts/minuto apresentaram chance 173\% superior de manter este nivel de atividade física após o ingresso na fase escolar (OR=2,73; IC95\% 0,98-7,59; $p=0,06)$. Verificou-se que a prática de atividade física na fase pré-escolar é preditora desta conduta após o ingresso na fase escolar. Sugere-se o desenvolvimento de campanhas a fim de informar pais e professores sobre a importância da aderência precoce às recomendaçôes de prática de atividades físicas.

Palavras-chave: Atividade motora; Criança; Pré-escolar.
1 University of Pernambuco. School of Physical Education. Research Group on Lifestyles and Health. Recife, PE. Brazil

2 Federal University of Santa Catarina. Sports Center. Florianópolis, SC. Brazil

3 Federal University of Pernambuco. Graduate Program in Physical Education. Recife PE. Brazil.

4 University of Pernambuco. Graduate Program in Physical Education. Recife PE. Brazil.

Received: September 18, 2018 Accepted: February 25, 2019

How to cite this article Barros SSH, Nahas MV, Hardman CM, Bezerra J, Barros MVG. Longitudinal follow-up of physical activity from preschool to school age: the ELOSPré study. Rev Bras Cineantropom Desempenho Hum 2019, 21:e59242. DOI: http://dx.doi.org/10.1590/19800037.2019v21e59242

Copyright: This work is licensed under a Creative Commons Attribution 4.0 International License. 


\section{INTRODUCTION}

Although scarce and marked by considerable methodological variability, studies with preschool children have shown high prevalence of low levels of physical activity and exposure to sedentary behaviors ${ }^{1}$. Regarding low level of physical activity, this finding was reported both in studies conducted in Brazil and in other countries ${ }^{2-5}$.

Low levels of physical activity observed in preschool children are worrisome because physically active lifestyle at this stage of life may be associated with health events that may manifest in both childhood and in other stages of life. Regarding the effects that can be observed already in childhood, a systematic review developed by Timmons et al. ${ }^{6}$ showed that physical activity is associated with lower body adiposity and improvement in motor performance, bone health, psychosocial adjustment and cardiometabolic health indicators. Other positive effects derived from the practice of physical activities in childhood also include better development of cognitive and mental functions, as well as improvement in school performance ${ }^{7,8}$.

Studies by Telama et al. ${ }^{9}$ and Dumith et al. ${ }^{10}$ indicated that the general level of physical activity of children and adolescents declines with advancing age; however, studies that indicate tendency to reduced level of physical activity were conducted with children closer to adolescence. Therefore, it is not known with safety and certainty, what occurs in the transition from the preschool age to the formal school age, which occurs from the age of 6-7 years. There are only few studies focusing on behavioral stability in relation to physical activity in this transition period in which profound changes occur in the routine of activities and in the physical and social environment of the school. The aim of the present study was to verify if the practice of physical activity in the preschool age (3-5 years) is a predictor of this behavior after entering the school age (5-7 years).

\section{METHOD}

This is a longitudinal study with a two-year follow-up. The first evaluation represented the baseline for the follow-up of participants and was carried out in 2010, while the second evaluation was carried out in 2012, always in the same period of the year (August to November) in order to avoid seasonal bias. This project is part of the "Longitudinal Observational Study on Health and Welfare of Children in Preschool Age" (ELOS-PRÉ) study and was approved by the Ethics Research Committee of the University of Pernambuco (CAAE: 0096.0 .097.000-10).

The target population of this study was delimited to the set of preschool children (3-5 years old) enrolled in public and private elementary schools of the city of Recife, Pernambuco. For purposes of sample planning, data from the Secretariat of Education were used, which in 2009, the study planning period, indicated that the target population was 49,338 children distributed in 782 schools. Kindergarten schools, in turn, were distributed in the area 
of coverage of the six political-administrative regions (RPAs) of Recife.

For sample calculation, criteria used in the design of cross-sectional prevalence studies were initially applied ${ }^{11}$. This option was due to the necessity that the baseline of the longitudinal study would allow the development of a series of nested cross-sectional studies. The following parameters were defined for the calculation of the initial sample size: (1) population estimated in 49,338 children; (2) estimated prevalence of the variables of interest in the researched population set at 50\%; (3) $95 \%$ confidence interval; (4) maximum tolerable error of four percentage points; and, (5) sampling design effect set at 1.5 due to the sample selection by clusters. Considering these parameters, the minimum sample should be composed of 890 participants. In order to deal with possible losses and refusals during data collection, the minimum sample size was increased by $20 \%$, resulting in a sample of 1,068 children.

To select the subjects, sampling procedure by single-stage clusters was adopted, where the sample unit was the kindergarten school. All public and private schools of the city of Recife with preschool classes were considered eligible for inclusion in the study. Taking into account a mean number of 38.5 children enrolled in each kindergarten school and in order to achieve the desired sample size $(n=1,068)$, it was established that data collection would be performed in 28 schools (sample units). The selection of these 28 schools was carried out respecting the proportionality of school distribution according to political-administrative regions (RPAs) and school type (public and private).

All selected schools allowed the study to be carried out and all children enrolled in preschool education were invited to participate, excluding those who were younger than 3 and older than 5 years. The exclusion of children outside the age group was performed after data collection because the accomplishment of this procedure in the field phase was not possible and adequate due to ethical and logistical reasons.

In the evaluation carried out in 2012, children who had been evaluated at baseline (2010) were followed, regardless of whether they remained in the same school where they were enrolled in 2010. All children who continued to live in Recife were included. To locate the children, telephone contact with parents was made in order to identify, in 2012, the schools in which the children were enrolled.

For data collection, a questionnaire specifically designed for the study was used (www.gpesupe.org/imagens/downloads/Quest_ELOS_Pr_2010. pdf). The instrument was designed to be applied through a face-to-face interview with mothers, parents or legal guardians of children, and consists of 120 questions distributed into 13 sections, namely: 1) child's affiliation and address; 2) socioeconomic, family and parents / guardians household information; 3) information on the environment of games and plays; 4) information on the child (5) information about the gestational period; 6) playing time outdoors; 7) TV, video game and computer time; 8) child's eating habits; 9) hygiene and oral health habits; 10) health and welfare 
indicators; 11) personal and behavioral information of parents; 12) body image; 13) level of physical activity of parents. In the development of the present study, data extracted from sections 2, 4 and 6 were used.

In addition, objective measures of physical activity were obtained by accelerometry, using Actigraph accelerometers (model GT3X +, ActiGraph, Pensacola, USA). Due to the availability of devices for data collection in 2010 , only one subsample $(n=180)$ of selected children was monitored. In 2012, all children who had been monitored in 2010 were sought so that they could be reassessed and parents interviewed. In the present study, 15 -second epochs were used. Parents were instructed on the use of accelerometers and trained by researchers to place the devices positioned at the waist to the right of the hip. All were instructed to place accelerometers on children early in the morning and to remove the device only when the child went to sleep, swim or take shower. During the monitoring period, parents were instructed to fill in a diary reporting the time of placing and removal of the device as well as the reasons for not using the accelerometers. Throughout the collection period, the team made telephone contacts with parents to identify possible doubts and difficulties in keeping the child with the device in use.

All children were monitored for at least seven consecutive days, including days of the weekend. After returning the equipment used in the monitoring, data were downloaded through the use of specific software (Actilife, version 6) for further treatment.

The reduction of raw data was also performed using Actilife software, adopting parameters suggested in literature ${ }^{12}$ and used in similar studies $^{13,14}$, in order to allow the comparison of results. To be included in analyses, the child should have at least three days of valid monitoring, one of which on the weekend. Previous studies have shown that three days of monitoring are sufficient to ensure reproducible and accurate measures of physical activity in children and to produce estimates of levels of physical activity similar to those that would be obtained for a greater number of valid days ${ }^{15}$. To consider one day of monitoring as valid, the child should have at least eight hours of equipment use on that day. When 60-minute periods of consecutive zeros were found in the data file, it was considered that accelerometers were not used by children and data from these periods were excluded from analyses.

The tabulation procedure was performed in an EpiData software file (version 3.1), using electronic control procedures in data entry. The SPSS software (version 10) was used to perform the analyses. Binary logistic regression analyses were used to test whether the level of physical activity (NAF) in the preschool age is a behavioral predictor in relation to physical activities presented in the school age, adjusting the analysis to other potential physical activity predictors. These analyses were performed for two specific outcomes, one derived from measures reported by parents (time spent in outdoor games and plays) and one obtained by direct monitoring via accelerometry (overall measure of the level of physical activity in cpm). 


\section{RESULTS}

As shown in Figure 1, of the 1,040 children who were assessed at baseline in 2010, 700 were located and evaluated in 2012, representing a follow-up (retention) rate of $67.3 \%$. Children who were not located, who were not authorized by parents or who did not agree to participate in the 2012 evaluation did not present demographic and anthropometric characteristics different from participants (Table 1). The only variable in which 'participants' and 'nonparticipants' (drop-outs) differed was in the proportion of children enrolled in public schools that was lower among 'non-participants', indicating that there was greater loss during follow-up among children enrolled in private schools.

In view of the logistic limitations for the monitoring of children with accelerometers, a sub-sample was selected, as described in the "methods" section. It was verified that children selected for accelerometry monitoring did not present demographic and anthropometric characteristics different from the other study participants (results not shown).

In the gross analysis, it was observed that the two outcomes observed in 2012 were significantly predicted by the corresponding level of physical activity measured in 2010. Regarding 'time spent in outdoor games and plays', crude analyses indicated that preschool children who spent 60+ minutes per day in this type of activity were $51 \%$ more likely of maintaining this behavior after entering school age $(\mathrm{OR}=1.51,95 \% \mathrm{CI} 1.08-2.10, \mathrm{p}=$ $0.02)$. After adjusting for these analyses, considering other potential predictors (covariables), there was only a slight attenuation in the magnitude of the OR value (Table 2).

Gross analyses also indicated that preschool children who in 2010 presented overall measure of level of physical activity of $300+$ counts / minute were $172 \%$ more likely of maintaining this level of physical activity after entering school age $(\mathrm{OR}=2.72,95 \% \mathrm{CI} 1.06-6.99, \mathrm{p}=0.04)$. This effect loses statistical significance after performing the adjusted analyses possibly due to the small sample size for the regression analyses, but the OR value remained unchanged (Table 3).

Table 1. Comparison of demographic and anthropometric characteristics observed at baseline (2010) of children who were followed from 2010 to 2012 (participants) and those who dropped out or were not located in the 2012 evaluation (drop-outs).

\begin{tabular}{llll}
\hline Variables & $\begin{array}{l}2010-2012 \text { (participants) } \\
\mathrm{n}=700\end{array}$ & $\begin{array}{l}2010- \\
\text { (drop-outs) } \\
\mathrm{n}=340\end{array}$ & $\mathrm{p}$-value \\
\hline Age (years) & $4.8 \pm 0.77(\mathrm{Md}=4.96)$ & $4.7 \pm 0.83(\mathrm{Md}=4.92)$ & 0.16 \\
Body mass $(\mathrm{kg})$ & $19.2 \pm 4.0(\mathrm{Md}=18.3) \mathrm{a}$ & $19.2 \pm 3.9(\mathrm{Md}=18.5) \mathrm{e}$ & 0.90 \\
Height $(\mathrm{cm})$ & $108.0 \pm 7.6(\mathrm{Md}=108.0) \mathrm{b}$ & $107.9 \pm 7.9(\mathrm{Md}=108.1) \mathrm{f}$ & 0.99 \\
Waist circumference (cm) & $53.7 \pm 5.7(\mathrm{Md}=52.4) \mathrm{c}$ & $53.5 \pm 5.3(\mathrm{Md}=52.0) \mathrm{g}$ & 0.76 \\
Boys, \% & 52.1 & 50.6 & 0.69 \\
Public school, \% & 46.1 & 34.7 & $<0.01$ \\
Shift-morning, \% & 51.1 & 45.9 & 0.13 \\
$\leq 2$ minimum wages, \% & $72.6 \mathrm{~d}$ & $70.0 \mathrm{~h}$ & 0.42
\end{tabular}

Note. * P-value relative to the Mann-Whitney U test for the comparison of variables on a numerical scale and the Chi-square test for the comparison of proportions. $M d=$ median value. Non existent data: $\mathrm{a}=30 ; \mathrm{b}=33 ; \mathrm{c}=37 ; \mathrm{d}=13 ; \mathrm{e}=21 ; \mathrm{f}=22 ; \mathrm{g}=24 ; \mathrm{h}=7$. 


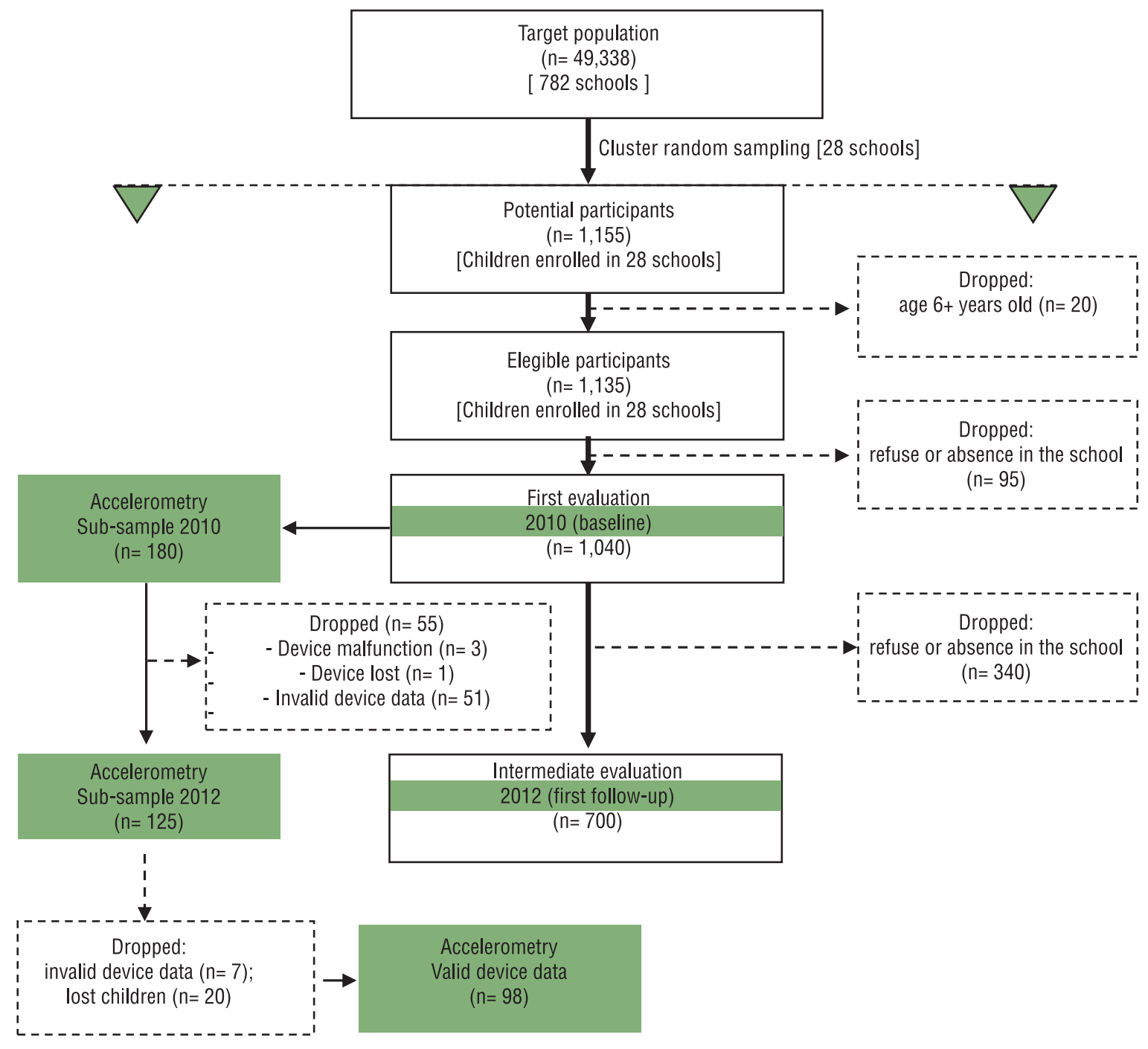

Figure 1. Flow chart of participants during the longitudinal study.

Table 2. Odds Ratio $(O R)$ and respective confidence intervals of being active (spending $60+\min /$ day on outdoor games and plays) at school age (2012 follow-up) considering the level of physical activity and other predictors observed in the preschool age (baseline, 2010).

\begin{tabular}{|c|c|c|c|c|c|}
\hline Model & Variable & Category & OR & $95 \% \mathrm{Cl}$ & $p$ \\
\hline \multirow{3}{*}{$1^{*}$} & Gender $^{\mathrm{a}}$ & Girls & 0.93 & $0.69-1.27$ & 0.67 \\
\hline & $\mathrm{Age}^{\mathrm{b}}$ & $\begin{array}{l}4 \text { years } \\
5 \text { years }\end{array}$ & $\begin{array}{l}1.20 \\
0.96\end{array}$ & $\begin{array}{l}0.76-1.89 \\
0.62-1.48\end{array}$ & $\begin{array}{l}0.43 \\
0.85\end{array}$ \\
\hline & Maternal schooling ${ }^{c}$ & Complete high school or higher & 1.17 & $0.42-1.64$ & 0.59 \\
\hline \multirow{3}{*}{2} & School type ${ }^{d}$ & Private & 0.99 & $0.73-1.34$ & 0.94 \\
\hline & Shift ${ }^{\mathrm{e}}$ & Afternoon & 1.04 & $0.77-1.42$ & 0.79 \\
\hline & $\begin{array}{l}\text { Participation of parents in PA with } \\
\text { their children }\end{array}$ & & 1.79 & $1.27-2.54$ & $<0.01$ \\
\hline \multirow{2}{*}{3} & Excess weight & & 0.56 & $0.39-0.80$ & $<0.01$ \\
\hline & Outdoor games and plays ${ }^{f}$ & $60+\min /$ day & 1.45 & $1.02-2.07$ & 0.04 \\
\hline
\end{tabular}

Note. Categories of reference: (a) boys; (b) 3 years; (c) Incomplete high school or lower; (d) public; (and) morning; (f) low active (<60 minutes / day). 
Table 3. Odds Ratio (OR) and respective confidence intervals of being active $(300+\mathrm{cpm})$ in school age (2012 follow-up) considering the level of physical activity and other predictive factors observed at preschool age (baseline, 2010).

\begin{tabular}{|c|c|c|c|c|c|}
\hline Model & Variable & Category & OR & $95 \% \mathrm{Cl}$ & $p$ \\
\hline \multirow[t]{3}{*}{$1^{*}$} & Gender ${ }^{a}$ & Girls & 0.94 & $0.42-2.13$ & 0.89 \\
\hline & $\mathrm{Age}^{\mathrm{b}}$ & $\begin{array}{l}4 \text { years } \\
5 \text { years }\end{array}$ & $\begin{array}{l}0.41 \\
0.18\end{array}$ & $\begin{array}{l}0.12-1.35 \\
0.05-0.60\end{array}$ & $\begin{array}{l}0.14 \\
0.01\end{array}$ \\
\hline & Maternal schooling ${ }^{c}$ & Complete high school or higher & 0.61 & $0.26-1.44$ & 0.26 \\
\hline \multirow[t]{4}{*}{2} & Age $^{b}$ & $\begin{array}{l}4 \text { years } \\
5 \text { years }\end{array}$ & $\begin{array}{l}0.43 \\
0.19\end{array}$ & $\begin{array}{l}0.13-1.43 \\
0.06-0.64\end{array}$ & $\begin{array}{l}0.17 \\
0.01\end{array}$ \\
\hline & School type ${ }^{d}$ & Private & 0.57 & $0.24-1.39$ & 0.22 \\
\hline & Shift ${ }^{\mathrm{e}}$ & Afternoon & 0.89 & $0.39-2.06$ & 0.79 \\
\hline & $\begin{array}{l}\text { Participation of parents in PA with their } \\
\text { children }\end{array}$ & & 1.14 & $0.43-3.01$ & 0.79 \\
\hline \multirow{3}{*}{3} & $\mathrm{Age}^{\mathrm{b}}$ & $\begin{array}{l}4 \text { years } \\
5 \text { years }\end{array}$ & $\begin{array}{l}0.42 \\
0.18\end{array}$ & $\begin{array}{l}0.10-1.78 \\
0.05-0.72\end{array}$ & $\begin{array}{l}0.24 \\
0.02\end{array}$ \\
\hline & Excess weight & & 0.84 & $0.24-2.92$ & 0.78 \\
\hline & General level of $\mathrm{PA}^{\dagger}$ & $300+\mathrm{cpm}$ & 2.73 & $0.98-7.59$ & 0.06 \\
\hline
\end{tabular}

Note. Categories of reference: (a) boys; (b) 3 years; (c) incomplete elementary school; (d) public; (and) morning; (f) <300 cpm.

\section{DISCUSSION}

The results of the present study indicated that the level of physical activity in the school age was significantly predicted by the behavior in relation to activities presented by children still in the preschool age. This finding was observed both in relation to the referred measure (time spent in outdoor games and plays) and the objective measure (cpm) of the level of physical activity. In addition, this finding was confirmed even after adjusting for other potential determinants of physical activity and confounding factors (i.e., gender, maternal schooling, and school type).

In general, there is still a great lack of studies of this nature and, in Brazil, there is no record of any research focusing on this subject and that had followed preschool children until the entry the school period. The lack of studies makes comparison of findings difficult. Only studies that have analyzed physical activity in childhood and in adulthood ${ }^{16}$, in adolescence and adulthood ${ }^{17}$ and physical activity in different phases of life can be found in literature?

In the present study, it was observed that the mean scores of the referred $(5.94 \pm 2.90 \times 5.09 \pm 2.67)$ and objective measure $(322.1 \pm 83.3 \times 269.3 \pm$ 80.0) of physical activity decreased modestly from preschool age to school age. A recent meta-analysis ${ }^{17}$ showed that physical activity declined during the transition from adolescence to adulthood (13 to 30 years). Data from the 49 reviewed studies indicated that moderate to vigorous physical activity (AFMV) decreased by an average of $5.2 \mathrm{~min} /$ day (or approximately 13\% from the baseline value). Most of these studies assessed physical activity by self-report, but nine studies using accelerometers showed an average decline of 7.4 minutes per day of AFMV (17\% from mean baseline value) between adolescence and adulthood.

The findings of this study also revealed that the tracking coefficient was 
low for the referred measure $(0.20, \mathrm{p}<0.01)$ and moderate for the objective measure $(0.44, \mathrm{p}<0.01)$ of the level of physical activity. Considering available studies ${ }^{18-23}$ conducted with preschool children, it was verified that the physical activity tracking coefficients vary from 0.1919 to 0.5721 . As observed in other studies ${ }^{9,24}$, physical activity tracking varies according to the indicator being analyzed, follow-up duration, study population and methods used to measure physical activity.

Although research on the stability of physical activity in the transition from preschool to school has shown a growth in recent years, some studies have been conducted analyzing the stability of physical activities performed in very specific contexts (recreation, sports) or periods of the day (afternoon) $)^{21,25}$.

The present study presents some limitations that deserve to be mentioned, as well as the procedures that have been adopted in order to attenuate them. First, considering the possibility of high sample loss, usually observed in longitudinal studies, it would be desirable for the initial sample to be greater to ensure sufficient statistical power for the intended analyses. This was not performed for logistical reasons and due to the scarcity of material and human resources to conduct a study involving larger number of participants. One of the measures adopted was to carry out extensive fieldwork in the second evaluation, including home visits with a view of locating the largest number of participants and reducing losses during the second evaluation. Second, in the first evaluation (baseline, 2010), the small number of accelerometers (only 25 devices) allowed to monitor only a subsample of participants in the ELOS-Pré project. Positively, participants were monitored for at least seven consecutive days, including during the period spent in school and weekend days. Third, measures referred to by parents do not allow capturing the physical activities carried out by children within the school and for operational reasons, it was not possible to rely on the collaboration of school teachers to provide data for all children individually. However, the measurement error derived from this limitation is randomly distributed in the sample in the two evaluations and, therefore, should not have compromised analyses performed in this study.

It is necessary to discuss and interpret the results of the present study considering these limitations. However, it is also important to consider some strengths of this study. First, the time of monitoring with accelerometers was at least seven days at both baseline and follow-up, allowing the maintenance of a larger number of children in the sample after applying data reduction and validation criteria. This is a strong point because in the study conducted by Edwards et al. ${ }^{19}$, children were monitored for only three days, resulting in significant loss of participants during data reduction and therefore during follow-up. In the study by Kelly et al. ${ }^{20}$, the number of monitoring days was different at baseline (3 days) and follow-up (7 days) evaluations, a methodological difference that offers the chance for potential assessment biases.

It was not possible to monitor all children selected for inclusion in the 
baseline with accelerometers. However, in general, the sub-sample presented the same characteristics of the study sample, as reported in results, assuming that there was no selection bias of children who were and were not monitored by accelerometry.

Finally, loss during follow-up was approximately $33 \%$, comparable to the retention rate achieved in studies conducted abroad ${ }^{26}$. In addition, the comparison between participants and drop-outs allowed identifying the lack of differences between them in terms of demographic and anthropometric characteristics.

\section{CONCLUSION}

It was concluded that the "time spent with outdoor games and plays" and the "overall measure of the level of physical activity (cpm)" measured in preschool children are factors capable of predicting their behavior in relation to the same variables after entry in school age. Thus, it is suggested the development of campaigns to inform parents and teachers about the importance of early adherence to physical activity recommendations.

\section{COMPLIANCE WITH ETHICAL STANDARDS}

\section{Funding}

This study was supported by the Coordination for the Improvement of Higher Education Personnel (CAPES), the National Council for Scientific and Technological Development (CNPq) and the Foundation for the Support of Science and Technology of the State of Pernambuco (FACEPE).

\section{Ethical approval}

Ethical approval was obtained from the local Human Research Ethics Committee - University of Pernambuco (Protocol No. 0096.0.097.000-10) was written in accordance with standards set by the Declaration of Helsinki.

\section{Conflict of interest statement}

The authors have no conflict of interests to declare.

\section{Author Contributions}

Conceived and designed experiments: SSHB, MVN, CMH, MVGB. Performed experiments: SSHB, CMH, JB, MVGB. Analyzed data: $\mathrm{CMH}$, MVGB. Contributed with reagents/materials/analysis tools: MVN, JB. Wrote the paper: SSHB, MVN, CMH, MVGB.

\section{REFERENCES}

1. Hnatiuk JA, Salmon J, Hinkley T, Okely AD, Trost S. A review of preschool children's physical activity and sedentary time using objective measures. Am J Prev Med 2014;4(4):487-497.

2. Reilly JJ, Jackson DM, Montgomery C, Kelly LA, Slater C, Grant S, et al. Total energy expenditure and physical activity in young Scottish children: mixed lon- 
gitudinal study. Lancet 2004;363(9404):211-212.

3. Kelly LA, Reilly JJ, Grant S, Paton JY. Low physical activity levels and high levels of sedentary behaviour are characteristic of rural Irish primary school children. Ir Med J 2005;98(5):138-141.

4. Barros SSH, Lopes AS, Barros MVG. Prevalência de baixo nível de atividade física em crianças pré-escolares. Rev Bras Cineantropom Desempenho Hum 2012;14(4):390-400.

5. Wanderley Júnior RS, Hardman CM, Oliveira ESA, Brito ALS, Barros SSH, Barros MVG. Fatores parentais associados à atividade física em pré-escolares: a importância da participação dos pais em atividades físicas realizadas pelos filhos. Rev Bras Ativ Fis Saúde 2013;18(2):205-214.

6. Timmons BW, Leblanc AG, Carson V, Connor Gorber S, Dillman C, Janssen I, et al. Systematic review of physical activity and health in the early years (aged 0-4 years). Appl Physiol Nutr Metab 2012;37(4):773-792.

7. Tomporowski PD, Davis CL, Miller PH, Naglieri JA. Exercise and children's intelligence, cognition, and academic achievement. Educ Psychol Rev 2008;20(2):111-131.

8. Singh JA, Furst DE, Bharat A, Curtis JR, Kavanaugh AF, Kremer JM. 2012 Update of the 2008 American College of Rheumatology recommendations for the use of disease-modifying antirheumatic drugs and biologic agents in the treatment of rheumatoid arthritis. Arthritis Care Res 2012;64(5):625-639.

9. Telama R, Yang X, Leskinen E, Kankaanpää A, Hirvensalo M, Tammelin T, et al. Tracking of physical activity from early childhood through youth into adulthood. Med Sci Sports Exerc 2014;46(5):955-962.

10. Dumith SC, Gigante DP, Domingues MR, Kohl HW 3rd. Physical activity change during adolescence: a systematic review and a pooled analysis. Int J Epidemiol 2011; 40(3):685-698.

11. Luiz RR, Magnanini MMF. A lógica da determinação do tamanho da amostra em investigações epidemiológicas. Cad Saúde Colet 2000;8(2):9-28.

12. Trost SG, Loprinzi PD, Moore R, Pfeiffer KA. Comparison of accelerometer cut points for predicting activity intensity in youth. Med Sci Sports Exerc 2011;43(7):1360-1368.

13. Francis SL, Morrissey JL, Letuchy EM, Levy SM, Janz KF. Ten-year objective physical activity tracking: Iowa Bone Development Study. Med Sci Sports Exerc 2013;45(8):1508-1514.

14. Cain KL, Sallis JF, Conway TL, Van Dyck D, Calhoon L. Using accelerometers in youth physical activity studies: a review of methods. J Phys Act Health 2013;10(3):437-450.

15. Lima RA, Barros SSH, Cardoso Júnior CG, Silva G, Farias Júnior JC, Andersen $\mathrm{LB}$, et al. Influence of number of days and valid hours using accelerometry on the estimates of physical activity level in preschool children from Recife, Pernambuco, Brazil. Rev Bras Cineantropom Desempenho Hum 2014;16(2):171-181.

16. KariJT, Tammelin TH, Viinikainen J, Hutri-Kähönen N, Raitakari OT, Pehkonen J. Childhood physical activity and adulthood earnings. Med Sci Sports Exerc 2016;48(7):1340-1346.

17. Corder K, Winpenny E, Love R, Brown HE, White M, Sluijs EV. Change in physical activity from adolescence to early adulthood: a systematic review and meta-analysis of longitudinal cohort studies. Br J Sports Med (in press).

18. Caldwell HA, Proudfoot NA, King-Dowling S, Di Cristofaro NA, Cairney J, Timmons BW. Tracking of physical activity and fitness during the early years. Appl Physiol Nutr Metab 2016;41(5):504-510.

19. Edwards NM, Khoury PR, Kalkwarf HJ, Woo JG, Claytor RP, Daniels SR. Tracking of accelerometer-measured physical activity in early childhood. Pediatr Exerc Sci 2013; 25(3):487-501.

20. Kelly LA, Reilly JJ, Jackson DM, Montgomery C, Grant S, Paton JY. Tracking physical activity and sedentary behavior in young children. Pediatr Exerc Sci 
2007;19(1):51-60.

21. Pate RR, Baranowski T, Dowda M, Trost SG. Tracking of physical activity in young children. Med Sci Sports Exerc 1996;28(1):92-96.

22. Potter M, Spence JC, Boulé N, Stearns JA, Carson V. Behavior tracking and 3-year longitudinal associations between physical activity, screen time, and fitness among young children. Pediatr Exerc Sci 2018;30(1):132-141.

23. Taylor RW, Murdoch L, Carter P, Gerrard DF, Williams SM, Taylor BJ. Longitudinal study of physical activity and inactivity in preschoolers: the FLAME study. Med Sci Sports Exerc 2009;41(1):96-102.

24. Jones RA, Hinkley T, Okely AD, Salmon J. Tracking physical activity and sedentary behavior in childhood: a systematic review. Am J Prev Med 2013;44(6):651-658.

25. Rauner A, Jekauc D, Mess F, Schmidt S, Woll A. Tracking physical activity in different settings from late childhood to early adulthood in Germany: the MoMo longitudinal study. BMC Public Health 2015;17;15:391.

26. Sigmund E, Sigmundová D, El Ansari W. Changes in physical activity in preschoolers and first-grade children: longitudinal study in the Czech Republic. Child Care Health Dev 2009;35(3):376-82.
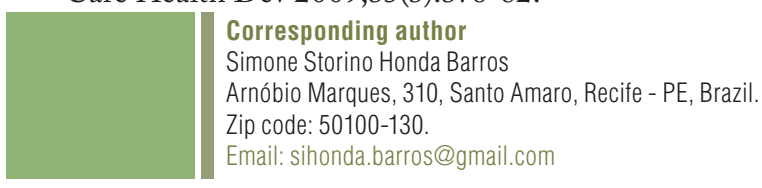